\title{
Perceptions of Small-Scale Poultry Farmers on the Effect of Micro-Credit on Livelihood in the Atwima Nwabiagya District of Ghana
}

\author{
Bannor Richard Kwasi ${ }^{1 *}$ Wayo Seini ${ }^{2}$ \\ ${ }^{1}$ Institute of Agribusiness Management, SK Rajasthan Agricultural University, India \\ ${ }^{2}$ Department of Agricultural Economics and Agribusiness, University of Ghana, Ghana
}

\begin{abstract}
This study was undertaken to assess the sources and effects of microfinance services on small-scale poultry farmers' livelihood in the Atwima Nwabiagya District in the Ashanti Region of Ghana. The studies have shown there has been improvement in the living conditions of the small scale poultry farmers following the receipt of microfinance services especially microcredit. Generally, positive changes were perceived by the farmers for almost all the indicators defined, such as increase in income, savings, and ability to purchase farm inputs, increase in household assets etc. On average, a high level of perceived effect by the farmers was achieved for farming activities and livelihood indicators defined and differing degrees of positive effects were recorded in each of the areas of indicators identified.
\end{abstract}

Keywords: Microfinance services, microcredit, small-scale poultry farmers, perception, effect, livelihood

\section{Introduction}

The economy of Ghana continues to be dominated by agriculture, absorbing over $60 \%$ of the economically active population and remains the highest contributor to GDP (about 40\%) among the main sectors of the economy (ISSER,2003). However Ghana's agriculture is predominantly small-scale and traditional where low resource technologies and purchased inputs are used (MOFA, 2003).

The poultry sub-sector is critically important in the context of agricultural growth and in the improvement of diets of people in Ghana. The sub-sector is particularly vital as a source for the supply of protein in the daily diet of the average household. It is characterized by large capital investments, mechanization and specialization. It also lends itself to small holder activity, hence an attractive economic activity, especially for women and poor populations. The sub-sector continues to grow as indicated by increased poultry population from 22.8million birds in 2001 to 24.25 million birds in 2002, an increase of $8.8 \%$ over 2001 (ISSER, 2003).

Commercial poultry production in Ghana started towards the end of 1950 and has gone through periods of prosperity and depressions. This industry, currently, has undergone an expansion in terms of the number of farms. This expansion is because of the increasing Ghanaian disposable income, rapid urbanization and the recent awareness of the nutritional value of poultry meat and eggs (Kese, 1988). Commercial poultry production could be more successful if provision of microfinance services especially microcredit is made available to smallscale poultry farmers.

According to Owusu-Acheampong (1986), the most critical factor for Ghana's development is provision of credit. He argued that with the proper utilization of credit, adequate inputs could be purchased to turn round the subsistence farming and produce enough to satisfy our needs and enhance farm incomes and living standards of peasant farmers.

However the formal banking sector assumes that the poor in developing countries like Ghana, earning incomes of less than a dollar per day, are not creditworthy because they lack the collateral and therefore, refuse them access to credit (Cheston and Kuhn, 2000). Many banks have noted that the transaction costs associated with operating in rural areas outweigh the income that may be earned and that there is a minimal level of business required for branches to reach the scale where they become viable (Coetzee, 1997). Consequently, most small-scale agro enterprises have either folded up or are operating at very low uneconomic levels.

For this reason, the Ministry of Food and Agriculture has credit facility for farmers in the district. NGOs namely Self-help, Heifer International and other rural banks and microfinance service providers also do give farmers financial services

In spite of these efforts and problems in the provision of microfinance services to farmers in district, no study has been conducted in the district to ascertain the effect of microfinance services on small scale poultry farmers. Therefore this study seeks to find answers to the following questions;

- What are the socio-demographic characteristics of small-scale poultry farmers in the district?

- What are the sources of micro financing for small scale poultry farmers in the district? 
- Has the provision microfinance services positively affected the livelihood of small scale poultry farmers?

\section{Materials And Methods}

The study was conducted in Atwima Nwabiagya District of the Ashanti Region in Ghana. It shares boarders with the Kumasi Metropolitan Assembly to the East, Ahafo Ano South and Atwima Mponua districts to the West, Kwabre and Offinso districts to the North, and Atwima districts to the South. The dependent population is the proportion of people catered for by those working or in the employable ages (15-64 years). This constitutes $48.7 \%$ of the total population of the district. The dependency ratio for Atwima Nwabiagya District is 97. This implies, 0.97 dependent per employable person. This is higher than the regional ratio of 92.0.The real dependency burden may be higher since the employable ages include a greater proportion of the unemployed and those in school/acquiring skills (Atwima Nwabiagya District Assembly, 2006)

\section{Research Design}

From the data of the Atwima District poultry farmers Association, the registered small- scale poultry farmers are 191 and out of this, a sample of 100 small-scale poultry farmers was taken. This represents $52.35 \%$ of the population of small-scale poultry farmers, which is large enough for the results of the analysis to be widely applicable.

\section{Sampling Technique}

Multi-stage sampling technique which comprises of Purposive sampling (target farmers) and simple random technique were used in the selection the small-scale poultry farmers and other stakeholders such as neighbours, relatives, money lenders and loan officers for the survey. The criteria for small-scale was any farmer who has 100 to 10,000 birds capacity. Fifteen neighbours and relatives of some farmers were interviewed to verify some perceptions they have about the farmers after receiving microcredit. Also, fifteen money lenders and loan officers that have given microfinance services to the sampled farmers were interviewed to verify some perceptions of the farmers.

The small-scale poultry farmers were asked to indicate their opinions on some indicators of their livelihoods before and after accessing microfinance services. Loan officers, money lenders, relatives and neighbours were also asked to indicate their opinions to verify what the farmers indicated. The means of their opinions (before and after accessing microfinance services) were calculated and tested for significance using paired t-test.

\section{Method of Data Analysis}

Descriptive statistics were used to analyse the data for objectives one to three. Descriptive statistics is a field that focuses on simply describing different characteristics of a data. The tools that were employed for the analysis using descriptive statistics are standard deviation, mean, frequency and percentages.

In addition the paired t-test was used to compare the significance of the sample means before and after accessing microfinance services for objective two.

\section{Theoretical framework}

The theoretical framework of the research is based on a livelihood framework. This livelihood framework is concerned first and foremost with people. It seeks to gain an accurate and realistic understanding of people's strengths (assets or capital endowments) and how they endeavour to convert these into positive livelihood outcomes.

Figure 1. The livelihood framework

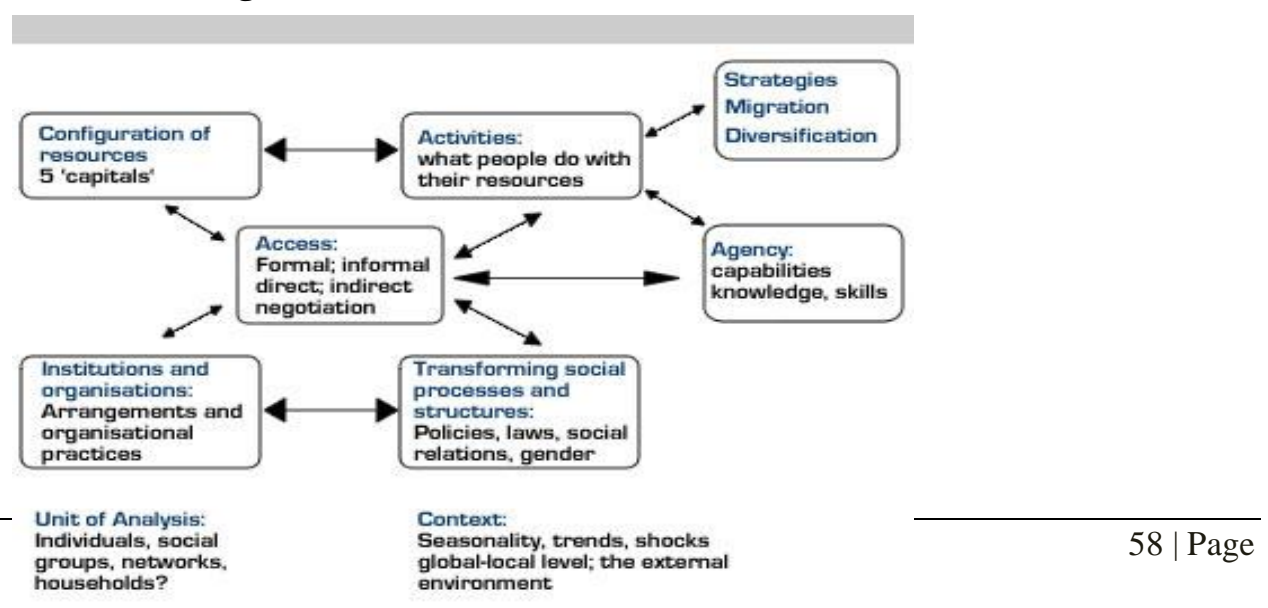


The figure 1 schematically presents the various components of an analytical framework to analyse livelihoods. The framework is founded on a belief that people require a range of assets or capitals to achieve positive livelihood outcomes; no single category of assets on its own is sufficient to yield all the many and varied livelihood outcomes that people seek. This is particularly true for poor people whose access to any given category of assets tends to be very limited. As a result they have to seek ways of nurturing and combining what assets they do have in innovative ways to ensure survival.

The livelihood framework identifies five core asset categories or types of capital upon which livelihoods are built namely natural capital, social capital, human, financial and physical capital DFID(1999).

\section{Socio-Demographic characteristic}

\section{Results And Discussion}

The demographic characteristics of the small-scale poultry farmers include age, level of education and number of years they have worked in the poultry industry.

Table 1: Age Group of the Respondents

\begin{tabular}{|c|c|c|}
\hline Age Group & Frequency & Percentage \\
\hline $20-25$ & 1 & 1 \\
\hline $26-30$ & 9 & 9 \\
\hline $31-35$ & 7 & 7 \\
\hline $36-40$ & 30 & 20 \\
\hline $41-45$ & 20 & 15 \\
\hline $46-50$ & 15 & 10 \\
\hline $51-55$ & 10 & 4 \\
\hline $56-60$ & 5 & 3 \\
\hline $61-65$ & 3 & $\mathbf{1 0 0}$ \\
\hline Total & $\mathbf{1 0 0}$ & \\
\hline
\end{tabular}

Source: Survey data (2008)

The age group with the highest frequency was 36-40 years and this represented $31 \%$ of the small-scale poultry farmers. The age groups 41-45 years, is the next highest frequency (20\%) in the age distribution. Also $15 \%$ small-scale poultry farmers were of the ages between $46-50$ and $10 \%$ for farmers between the ages of 5156years. In addition $4 \%$ of the farmers have their ages between 56-60years and the lowest frequency is farmers of the ages between 21-25years with farmers of the ages between 61-65years having the second lowest frequency representing $1 \%$ and $3 \%$ of the farmers interviewed.

The results show that majority of the farmers interviewed are in their middle age group and are therefore potentially capable of working very hard to increase agricultural productivity. Tauer (2000) observed that when farmers enter their midlife (35-40) they typically see an increase in productivity as they gain both experience and equity. At the age of 35years, productivity begins to increase up to the 60years.

Table 2: Cross Tabulation of Years of Experience and Level of Education of Respondents

\begin{tabular}{|l|c|c|c|c|c|c|c|}
\hline \multirow{2}{*}{$\begin{array}{l}\text { Years of } \\
\text { Experience }\end{array}$} & \multicolumn{7}{|c|}{ Level of Education of Respondents } \\
\cline { 2 - 9 } & $\begin{array}{c}\text { No } \\
\text { Schooling }\end{array}$ & $\begin{array}{c}\text { Non- } \\
\text { Formal }\end{array}$ & Primary & Middle & Vocational & Sec/Tech & Total \\
\hline $3-10$ & 2 & 4 & 13 & 3 & 3 & 4 & $\mathbf{2 9}$ \\
\hline $11-18$ & 17 & 17 & 1 & 4 & 1 & 0 & $\mathbf{4 0}$ \\
\hline $19-27$ & 4 & 4 & 12 & 4 & 0 & 1 & $\mathbf{2 5}$ \\
\hline $28-36$ & 1 & 0 & 4 & 0 & 0 & 0 & $\mathbf{5}$ \\
\hline 37 \& Above & 1 & 0 & 0 & 0 & 0 & 0 & $\mathbf{1}$ \\
\hline Total & $\mathbf{2 5}$ & $\mathbf{2 5}$ & $\mathbf{3 0}$ & $\mathbf{1 1}$ & $\mathbf{4}$ & $\mathbf{5}$ & $\mathbf{1 0 0}$ \\
\hline
\end{tabular}

Source: Survey data (2008)

$25 \%$ of the farmers interviewed had no-schooling while another $25 \%$ had non-formal education where they had been taught how to read and write in Ghanaian languages. Thus, $50 \%$ of the sample had no formal education. The farmers that have Middle School education and Vocational education were 11 and 4 representing $11 \%$ and $4 \%$ respectively.

In addition it was observed that the level of formal education of majority of the small-scale poultry farmers interviewed was low ( $41 \%$ had no post basic education). About three years of experience and at least 
basic formal education are necessary for agricultural managers. Low level of education of the farmers can have negative effect in seeking loans from the formal banking sector because in the formal banking sector, borrowers are required to write application letters and complete relevant documents before credit is disbursed to them (Neumann and Hamp, 1999). Table 2 again, shows that the highest frequency for the number of years farmers interviewed have worked in the poultry industry is $11-18$ years representing $40 \%$ of the farmers. This is followed by 3-10 years of experience representing $29 \%$ of farmers and 19-27 years representing $25 \%$ of the small-scale poultry farmers in the district. Only $5 \%$ and $1 \%$ have worked in the industry for 28-36years and 37 years and above respectively.

The range of experience shows that small-scale poultry farmers in the district have appreciable experience in the field and coupled with some form of education for the farmers in the district will increase productivity. This is because according to the report by Bureau of Labour Statistics (2002-03) experience and some formal education are necessary for agricultural managers to increase productivity.

Moreover illiteracy level should be considered by various stakeholders when designing programmes and technologies in the study area in order to make exchange of information effective and efficient.

Table 3: Effect of Microfinance services on the livelihood of Small-Scale poultry farmers

\begin{tabular}{|l|c|c|c|c|c|c|c|}
\hline \multicolumn{1}{|c|}{$\begin{array}{l}\text { Aspect of Livelihood } \\
\text { Statement }\end{array}$} & \multicolumn{2}{|c|}{ Means } & \multicolumn{3}{c|}{ S.D } & \multicolumn{3}{c|}{ Paired T test } \\
\cline { 2 - 8 } & before & after & before & after & & df & $\begin{array}{c}\text { Sig(2- } \\
\text { tailed) }\end{array}$ \\
\hline Monthly Income & 1.09 & 4.08 & 0.58 & 0.88 & -21.61 & 95 & 0.000 \\
\hline Monthly Savings & 1.79 & 4.27 & 0.81 & 0.76 & -21.56 & 95 & 0.000 \\
\hline $\begin{array}{l}\text { Level of Participation in } \\
\text { decision making }\end{array}$ & 2.27 & 4.30 & 1.34 & 0.69 & -14.70 & 95 & 0.050 \\
\hline $\begin{array}{l}\text { Borrowing from Money } \\
\text { Lenders }\end{array}$ & 1.80 & 4.07 & 0.67 & 0.82 & -19.99 & 95 & 0.045 \\
\hline $\begin{array}{l}\text { Respect from my family } \\
\text { members }\end{array}$ & 1.87 & 4.12 & 0.71 & 0.88 & -21.27 & 95 & 0.030 \\
\hline $\begin{array}{l}\text { Payment of my Children's } \\
\text { School Fees }\end{array}$ & 2.04 & 4.18 & 0.60 & 0.94 & -19.27 & 95 & 0.011 \\
\hline Payment of medical bills & 1.64 & 4.29 & 0.80 & 0.88 & -24.40 & 95 & 0.021 \\
\hline Household Assets & 2.29 & 4.15 & 0.86 & 0.82 & -16.62 & 95 & 0.000 \\
\hline $\begin{array}{l}\text { Donation at Church, } \\
\begin{array}{l}\text { Mosque and other Social } \\
\text { gatherings }\end{array}\end{array}$ & 1.84 & 3.91 & 0.79 & 1.07 & -17.02 & 95 & 0.032 \\
\hline $\begin{array}{l}\text { Contact with Agric } \\
\text { Extension Agents }\end{array}$ & 2.22 & 4.23 & 0.84 & 0.85 & -16.06 & 95 & 0.050 \\
\hline $\begin{array}{l}\text { Devotion and Prayer } \\
\text { Activities }\end{array}$ & 3.99 & 1.55 & 1.18 & 0.88 & 12.86 & 95 & 0.010 \\
\hline Source: Survey data (2008)
\end{tabular}

The results of their opinions are as follows:

Before the farmers accessed microfinance services(microcredit and financial literacy training) their monthly income and savings were low (1.09 and 1.79). However, after accessing microfinance services the means of their income and savings were high (4.08 and 4.27 respectively). This shows that microfinance services according to the respondents had positive impact on their monthly incomes and savings. Again, the results show that, the level of participation in decision-making in the family and community level of the farmers before assessing microfinance credit was 2.27 as against 4.30 after accessing microfinance credit in the form of training, credit and savings. This finding shows that microfinance credit really has significant effect on the level of decision making even though they express diverse opinions on the effect considering the standard deviation of 1.34 and 0.69 . However, when relatives and neigbours were interviewed, the result shows it was not significant. Respect from family members saw a significantly increased from a mean of 1.87 to 4.12 as a result of microfinance services especially microcredit and training. One middle aged male respondent proudly stated "I can now provide leadership in the house as a man because I have money to maintain and dignify the family".

Furthermore, the results also revealed that the small-scale poultry farmer's ability to pay medical bills and contact with agricultural extension officers has increased. Most of the farmers mentioned that, with the privitisation of the veterinary services "if you don't have money it will be very difficult to get the services of the veterinary officers of the Ministry of Food and Agriculture". 
The results further revealed that, prior to accessing microfinance credit, the donation at church, mosque and other social gatherings by these beneficiaries were low, given a mean of 1.84. However after accessing microfinance credit there was a significant increase in donation at social gatherings including church and mosque. Afrane (2005) also reported that financial contributions to church activities improved significantly with respondents recording an impressive positive impact of $74 \%$.

For devotion and prayers before and after accessing microfinance credit, the results gave negative correlation. It gave a mean of 3.99 before accessing microfinance credit and 2.25 after accessing microfinance credit. This implies that as the income of these farmers increase and they give more donations at social gatherings there is also a significant negative effect on their spiritual life. This finding was found mostly among the professed Christians. One farmer stated "If I have prayed to God to give me money and business should also boom and He has given me, then he doesn't think he needs to be going to all sort of church meetings at the expense of his work". In similar research by Afrane (2005), "three levels of spiritual indicators scored low levels of impact: church attendance, prayer and devotion activities and participation in religious activities. This observation implies economic prosperity also tends to impact negatively on peoples attitude toward spiritual issues, as has been in many rich countries".

The results further revealed household assets of the respondents have increased after accessing microfinance credit. Before accessing microfinance credit the mean of household assets was 2.29 whiles after accessing microfinance credit it was 4.15.Commenting on this, farmers showed fridges, furniture's, radios, televisions and other household assets bought as a result of the spillover effect after accessing microcredit to support their businesses.

\section{Sources of Microfinance Services}

Table 4 below shows that, farmers get microfinance services such as microcredit, savings and financial literacy training from both the formal and informal sector. The formal sector gives about $30 \%$ of the microfinance services given to the small-scale poultry farmers with ProCredit giving the highest percentage of $20 \%$ out of the $40 \%$ of microcredit given by the formal sector.

Table 4: Sources of Microfinance services

\begin{tabular}{|l|c|c|}
\hline SOURCES OF MICROFINANCE SERVICES & PERCENTAGE & SERVICES PROVIDED \\
\hline Atwima Kwawonma Rural Bank & 5 & Microcredit, savings \\
\hline Atwima Mponua Rural Bank & 5 & Microcredit and savings \\
\hline ProCredit & 20 & $\begin{array}{c}\text { Microcredit and financial literacy } \\
\text { training }\end{array}$ \\
\hline Credit Union & 10 & Microcredit and savings \\
\hline Susu & 15 & Microcredit and savings \\
\hline Private Money Lender & 30 & Microcredit \\
\hline & & Microcredit \\
\hline Friends & 5 & Microcredit \\
\hline Relatives & 10 & $\mathbf{1 0 0}$ \\
\hline Total & & \\
\hline
\end{tabular}

Source: Survey data (2008)

The type of services given to farmers by these formal institutions are mostly credit with little training on farm budgeting, proper record keeping and farm management. However, the informal sector has the highest percentage $(60 \%)$ of microfinance services (microcredit) given to poultry farmers in the district. The informal sector gives mainly microcredit to these small- scale poultry farmers.

Assigning reasons for why farmer's access microfinance services especially credit from the informal sector Newmman and Hamp, (1999) reported that borrowers see microfinance credit from the informal sector as less time consuming since in the formal banking sector application and screening process required much time. Also no collateral is required as is the case in formal banking practices.

Assigning reasons why most of the farmers who access microcredit from the formal sector, accessed the loans from ProCredit, they were of the view that it was quite easier with document processing and valuing some assets such as farming equipment, fridges, television as collateral for getting the loan. Also they use reducing balance interest rates on agro loans compared to other microcredit providers in the district, who use compound interest rates. 


\section{Conclusion}

- From the findings, it is clear that microfinance services are perceived to have positive influence on the livelihood of small-scale poultry farmers in the Atwima Nwabiagya district, as it has enabled them to settle their medical bills, pay their children school fees, own household assets such televisions, home theatres, fridges, irons e.t.c. and also saved some money.

- Microfinance services have also enhanced their status in their communities as they are able to participate in community and extended family decision making process and make donations at social gatherings.

- The study also revealed shows that, farmers get microfinance services such as microcredit, savings and financial literacy training from both the formal and informal sector. The formal sector gives about $30 \%$ of the microfinance services and informal sector contributes 70\%. It is therefore important that, the District Assemblies, Ministry of Food and Agriculture, Non-Governmental Agencies and formal financial institutions pay more attention to the delivery of microfinance services to small-scale poultry farmers in the district since the farmers perceived that microfinance services have positive effect on their livelihood regardless of the constraints

- The limitation of this paper is its inability to use higher analytical models to empirically determine the effect of microfinance services on livelihood farmers in the district

\section{References}

[1]. Afrane. S. (2005). Impact Assessment of Microfinance Interventions in Ghana and South Africa: A synthesis of Major Impacts and Lessons. Journal on Microfinance. Volume 4, Number 1, Pages 38-56.

[2]. Atwima Nwabiagya District Assembly (2006). Agriculture, Major Economic Activities, Demographic Features. Retrieved on February 13, 2008 from http://www.atwimanwabiagya.ghanadistricts.gov.gh.htm

[3]. Cheston, S. and Kuhn, L. (2000). Empowering women through microfinance, Summary of Group Business. Retrieved on January 20, 2007 from http://www.microcreditsummit.org/papers/empowerinto.htm

[4]. Coetzee, G: K: (1997). Institutional Change in Rural Financial Market in South Africa. Unpublished PHD Thesis, University of Pretoria, Pretoria.

[5]. DFID( 1999). Sustainable Livelihoods Guidance Sheets. London: DFID.

[6]. ISSER (2003), The State of the Ghanaian Economy in 2002, Pub. University Book Press. Pp.90.

[7]. MOFA (2003). Agricultural Extension Policy. Directorate of Agricultural Extension Services, Ministry of Food and Agriculture, Accra.

[8]. Neumman, and Hamp, M. (1999). “The Union Nationale des Cooperatives Agricoles deCredit et d'Epargne” in Mauritanina. Agriculture and Rural Development, 6,52.

[9]. Owusu-Acheampong, J. H. (1986). "Rural Credit and Rural Development in Ghana" In C.K. Brown, ed., Rural Development in Ghana. Accra: Ghana Universities Press, pp 90-104.

[10]. Tauer, L. (2000). Old Farmers are not Productive: They Just need New Tractor. America News Service. May 2000. 